\title{
INTERACTIONS OF AROMATASE AND SELADIN-1: A NEUROSTEROIDOGENIC AND GENDER PERSPECTIVE
}

Abstract

Aromatase and seladin-1 are enzymes that have major roles in estrogen synthesis and are important in both brain physiology and pathology. Aromatase is the key enzyme that catalyzes estrogen biosynthesis from androgen precursors and regulates the brain's neurosteroidogenic activity. Seladin-1 is the enzyme that catalyzes the last step in the biosynthesis of cholesterol, the precursor of all hormones, from desmosterol. Studies indicated that seladin-1 is a downstream mediator of the neuroprotective activity of estrogen. Recently, we also showed that there is an interaction between aromatase and seladin-1 in the brain. Therefore, the expression of local brain aromatase and seladin-1 is important, as they produce neuroactive steroids in the brain for the protection of neuronal damage. Increasing steroid biosynthesis specifically in the central nervous system (CNS) without affecting peripheral hormone levels may be possible by manipulating brain-specific promoters of steroidogenic enzymes. This review emphasizes that local estrogen, rather than plasma estrogen, may be responsible for estrogens' protective effects in the brain. Therefore, the roles of aromatase and seladin- 1 and their interactions in neurodegenerative events such as Alzheimer's disease (AD), ischemia/reperfusion injury (stroke), and epilepsy are also discussed in this review.

\section{Introduction}

Neuroactive steroids, or neurosteroids, are produced peripherally by exocrine glands, such as the ovaries and adrenal glands, and can cross the blood-brain barrier to influence neuronal signaling [1, 2]. They play important roles in the neuroendocrine control of brain excitability based on their conversion to different metabolites, such as androstenediol and estradiol $\left(\mathrm{E}_{2}\right)$ [3-6].

Even though the brain is only $2 \%$ of body weight, it contains $25 \%$ of the total body cholesterol, the main precursor of all hormones [7]. Brain cholesterol is involved in myelin sheath formation, synaptogenesis, neurotransmission, and neurosteroidogenesis [8-13]. Although peripherally produced neurosteroids directly influence brain functions, it is well-established that the nervous system is also a steroidogenic tissue and expresses enzymes that are involved in the synthesis and metabolism of steroids. This unique ability of neurosteroidogenesis allows the brain to produce specific steroids required for neuroendocrine control and allows the brain to protect itself from neurodegeneration [14] (Fig. 1).

Two enzymes come into the foreground when discussing neuroprotective activity: Aromatase, which converts estrogen from androgen during the last step of estrogen biosynthesis from cholesterol, and seladin-1, which synthesizes cholesterol from desmosterol (Table 1). The reason why these two enzymes are emphasized in neurodegeneration is hidden in the internal dynamics of the brain. It is well known that estrogens exert neurotrophic and neuroprotective effects by stimulating the expression of neurotrophins and cellsurvival factors, enhancing synaptic plasticity, and by acting as antioxidants. Estrogens are protective under numerous types of stressors, including oxidative stress, glutamate excitotoxicity, chemical lesions, traumatic or mechanical injuries, ischemia, iron toxicity, glucose or serum deprivation, and specialized disease related pathogens, such as amyloid beta $(A \beta)$ and HIV proteins [15]. Aromatasemediated estrogen formation in the brain is known to have regulatory effects on synaptic
Pelin Kelicen-Ugur ${ }^{1 *}$ Mehtap Cincioğlu-Palabıyık²,

Hande Çelik',

Hande Karahan ${ }^{3,4}$

${ }^{1}$ Hacettepe University, Faculty of Pharmacy, Department of Pharmacology, Sihhiye Ankara Turkey

${ }^{2}$ Turkish Medicines and Medical Devices Agency (TITCK), Department of Regulatory Affairs, Division of Pharmacological Assessment, Ankara, Turkey

${ }^{3}$ Stark Neurosciences Research Institute, Indiana University School of Medicine, Indianapolis, IN, USA

${ }^{4}$ Department of Medical and Molecular Genetics, Indiana University School of Medicine Indianapolis, IN, USA

Received 08 March 2019 accepted 03 October 2019

*E-mail:pkelicen@hacettepe.edu.tr

(c))BY 2019 Pelin Kelicen-Ugur et al. published by De Gruyter.

This work is licensed under the Creative Commons Attribution 4.0 Public License.

plasticity, neural stem cell (NSC) proliferation, neurogenesis, newborn neuron migration, differentiation, survival, and neuroprotection [13, 15-23].

The expression of aromatase is regulated through the alternative use of multiple, promoter-specific first exons (reviewed in [24]). These first exons, which remain untranslated, are spliced into the coding exons 2 through 10 of the aromatase gene, resulting in numerous aromatase transcripts, all of which code for the same protein (reviewed in [24]). Because the brain-tissue specific aromatase promoter (I.f) is known, designing a drug to increase local estrogen levels in the brain by targeting brainspecific aromatase transcription is theoretically possible [25-27].

Therefore, increasing steroid biosynthesis specifically in the CNS (central nervous system) without affecting peripheral hormone levels may be possible by manipulating brain-specific promoters of steroidogenic enzymes or by post-translationally modifying their protein isoforms. Regulation of estrogen synthesis in the CNS may be achieved by developing 
aromatase modulators and can provide new approaches for the prevention and therapy of the neurodegenerative diseases.

\section{Aromatase and Brain Physiology and Pathology: Estrogen- dependent action}

First, the role of aromatase in physiological events will be discussed before elaborating on its role in brain pathology (Fig. 2). Aromatase is the key enzyme catalyzing estrogen biosynthesis from androgen precursors, such as testosterone. It is mainly a member of the cytochrome P450 enzyme family and is encoded by the CYP19 gene [28].

Aromatase and its neuroprotective activity in the brain were discovered by Naftolin in 1976 [29]. Brain aromatase is normally synthesized in nerve cells and regulates neuronal differentiation, neural, and synaptic activity and plasticity, neurogenesis, memory, and cognitive functions by producing estrogen locally [13, 14, 16, 17, 20-23].

When the aromatase gene was examined in detail, researchers discovered that it was encoded by different promoters in different tissues (reviewed in [24]). In vertebrate brains, aromatase is synthesized primarily through promoter I.f in the hypothalamus, hippocampus, and amygdala [27].

Studies conducted to understand the physiological significance of aromatase showed that aromatase knock-out (ArKO) male mice demonstrated aggressive behavior patterns [30], while depressive symptoms were observed in ArKO female rats [31] and women carrying the CYP19 polymorphism [32]. The chronic use of aromatase inhibitors in women with breast cancer causes damage to visual and spatial memory [33, 34]. Aromatase inhibition in CA1 pyramidal hippocampal neurons or in vitro siRNA silencing of aromatase in neuronal cultures results in decreased numbers of dendrites and synapses that cannot be restored by exogenous estrogen therapy. ArKO rats are more susceptible to excitotoxic damage compared to normal rats after chronic systemic or intracerebroventricular aromatase inhibitor administration [35-38].

While neuronal aromatase predominates in physiological events, astrocytic aromatase

Table 1. Comparison of aromatase and seladin-1.

\begin{tabular}{cc}
\hline ENZYME & \\
\hline $\begin{array}{c}\text { Aromatase } \\
\text { (Estrogen synthase) }\end{array}$ & $\begin{array}{c}\text { Seladin-1 } \\
\text { GENE }\end{array}$ \\
CYP19A1 & $\begin{array}{c}\text { (Selective Alzheimer's Disease Indicator-1; } \\
\text { 3-beta-hydroxysterol delta-24-reductase) }\end{array}$ \\
Brain specific promoter I.f & \\
LOCALIZATION & DHCR24 \\
Cytoplasmic and presynaptic & \\
Over granulosa cells, testis, adipose tissue, & \\
Placenta, & Endoplasmic reticulum and Golgi \\
Subcutaneous fat tissue, & Adrenals, \\
Liver, & Pituitary, \\
Muscle, & Thyroids, \\
Ovaries,
\end{tabular}

\section{FUNCTION}

Androgen $\rightarrow$ Estrogen

Normally synthesized in the nerve cells and regulates neuronal differentiation, neural and synaptic activity and plasticity, neurogenesis, memory and cognitive functions by producing local estrogen. Its expression increased as an acute response to neurodegenerative damage.

Its expression decreased in Alzheimer's Disease.
Desmosterol $\rightarrow$ Cholesterol Normally synthesized in the nerve cells, provides membrane barrier structure and protects neurons from apoptotic cell death by inhibiting caspase- 3 activity, $A \beta$ toxicity and oxidative stress.

Its expression increased as an acute response to neurodegenerative damage. Its expression decreased in Alzheimer's Disease.

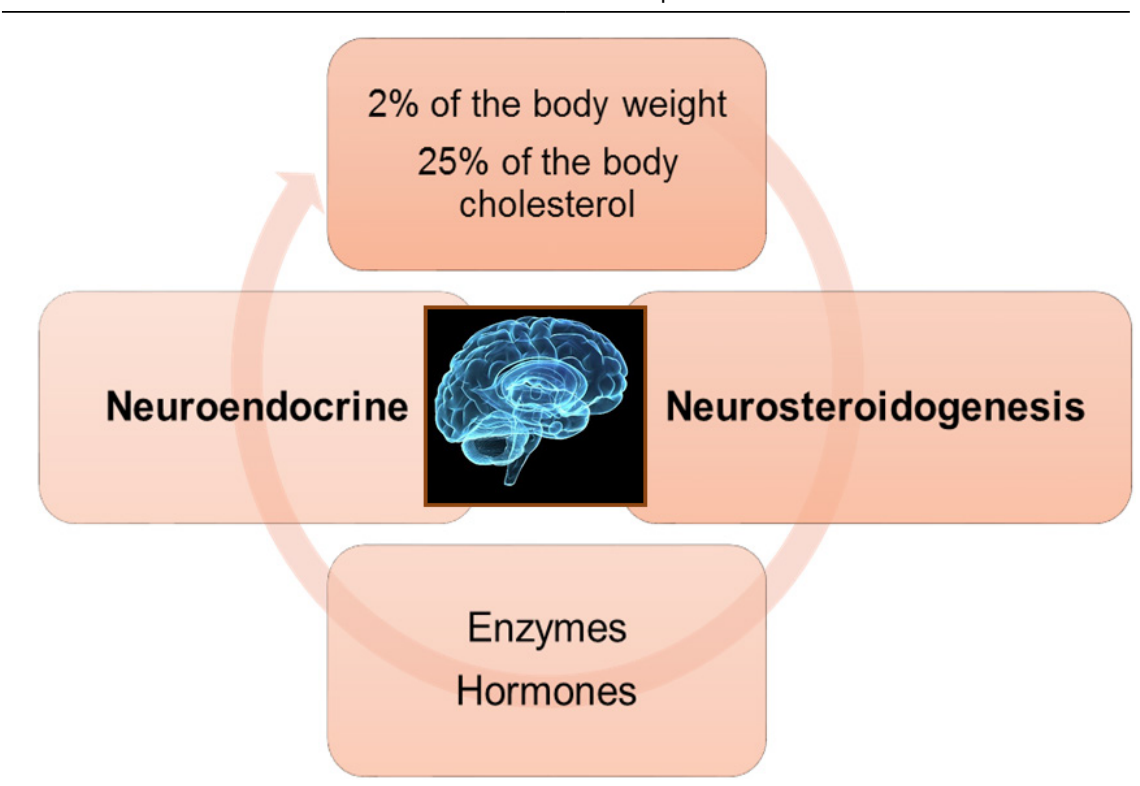

Figure 1. Neuroendocrine and neurosteroidogenic functions of the brain. The brain contains $25 \%$ of the total body cholesterol, the main precursor of all hormones [7] and has unique ability of neurosteroidogenesis, which allows the brain to produce specific steroids required for neuroendocrine control and to protect itself from neurodegeneration.

participates in pathological conditions [39-43]. Indeed, glial aromatase expression increases in the early stages of neurodegenerative damage and triggers protective local estrogen synthesis. The neuronal aromatase that is predominant during physiological conditions is replaced by glial aromatase, especially around damaged neurons. While neurons continue 


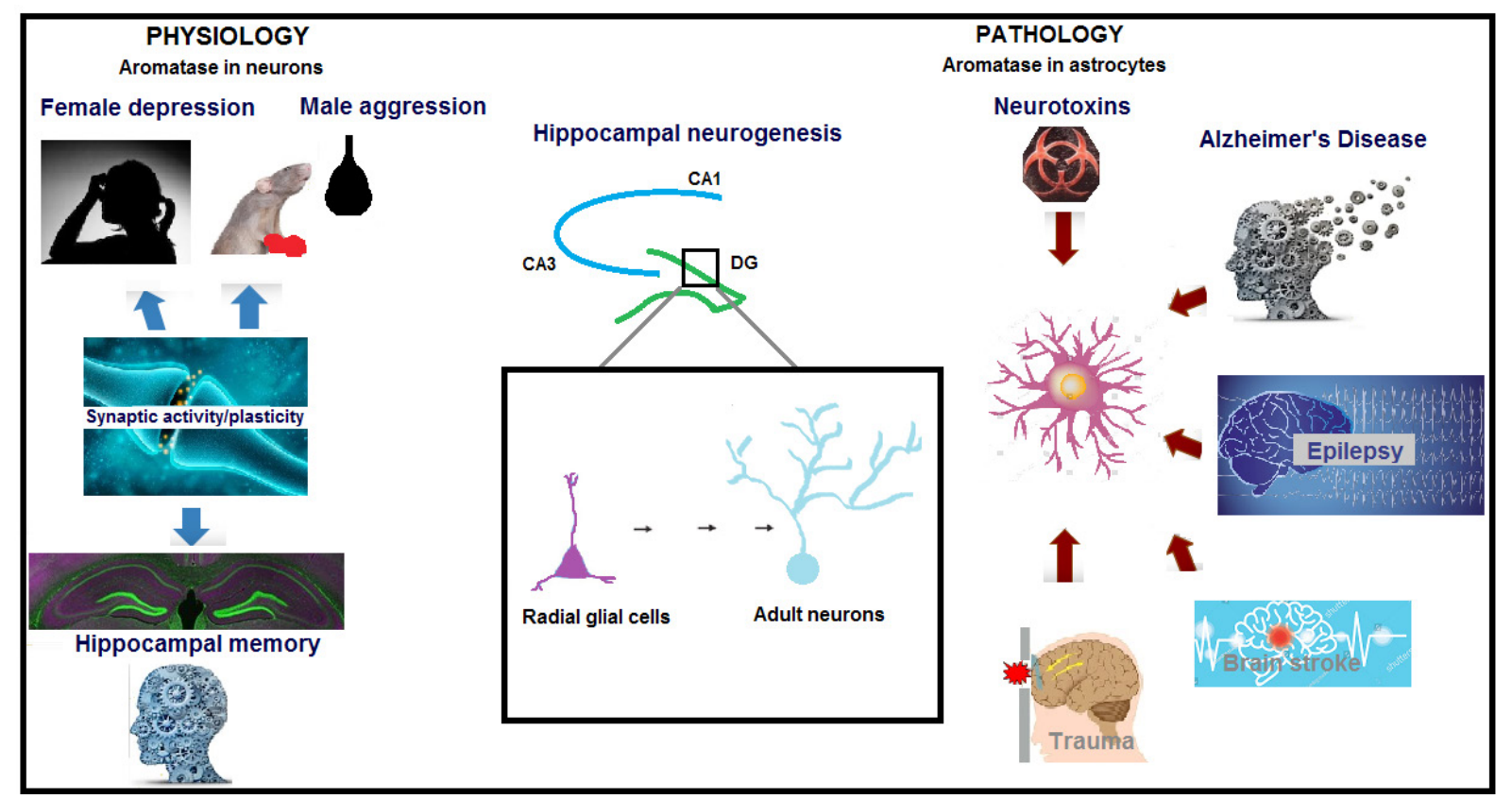

Figure 2. Aromatase in brain physiology and pathology. Brain aromatase is normally synthesized in nerve cells and regulates neuronal differentiation, neural and synaptic activity and plasticity, neurogenesis, memory, and cognitive functions by producing estrogen locally [13,14, 16, 17, 20-23]. Aromatase knock-out (ArKO) male mice demonstrated aggressive behavior patterns [30], while depressive symptoms were observed in ArKO female rats [31] and women carrying the CYP19 polymorphism [32]. The chronic use of aromatase inhibitors in women with breast cancer causes damage to visual and spatial memory [33, 34]. Glial aromatase expression increases in the early stages of neurodegenerative damage and triggers protective local estrogen synthesis [18, 23, 41]. Neurotoxic and mechanical lesions, head trauma, ischemic insults, such as middle cerebral artery occlusion (MCAO), and global brain ischemia result in de novo enzyme expression in reactive astrocytes. Aromatase expression and local estrogen production also regulate hippocampal neurogenesis [58-60].

to produce aromatase, glial cells begin to produce de novo aromatase synthesis around the damage site $[18,23,41]$. Neurotoxic and mechanical lesions, head trauma, ischemic insults, such as middle cerebral artery occlusion (MCAO), and global brain ischemia result in de novo enzyme expression in reactive astrocytes. Increased aromatase expression in astrocytes after brain injury is followed by a significant increase in enzymatic activity and increased levels of $E_{2}$ and estrogen receptor-alpha (ERa) in the brain. Therefore, it can be said that aromatase-mediated estrogen conversion from steroid precursors is an endogenous defense mechanism of the brain against neurodegeneration [41, 43-46].

Adult neurogenesis (Fig. 2) involves aromatase activity and has been studied extensively in zebra finch [47-51] and zebrafish (teleofish) brains [52-57]. In mammals, radial glial cells (RGCs) behave as neural stem cells during embryonic development and transform into astrocytes at the perinatal stage [48-50]. In fish, they persist during adulthood and maintain neural progenitor properties [52-
57]. When a hippocampal lesion is formed, astrocytes express aromatase and produces estrogen, which then acts as a messenger and allows astrocytes to communicate with the RGCs. RGCs are progenitor cells that express aromatase and are located in the subventricular zone around the brain ventricles. Studies observed that RGCs migrate to damaged sites in the brain and accumulate around lesions. Treatment of these cells with an aromatase inhibitor, letrozole, or silencing of the cholesterol carrier steroidogenic acute regulatory protein (StAR) with siRNA has been shown to decrease the number of RGCs and induce apoptotic cell death. This data confirms that aromatase expression and local estrogen production regulate hippocampal neurogenesis [58-60].

It is well-known that $A \beta$ accumulates in $A D$ brains. In hippocampal neurons, estrogen has been shown to protect neuronal cells from $A \beta$-mediated cell death by decreasing $A \beta$ production and increasing $A \beta$ clearance (as reviewed in [61]). Additionally, $E_{2}$ reduces A $\beta$-induced calcium elevation $\left(\mathrm{Ca}^{2+}\right)$ in hippocampal neurons [62] and prevents the hyperphosphorylation of tau, another pathological hallmark of $A D$ (as reviewed in [63]). Importantly, brains of late-stage $A D$ patients have significantly reduced aromatase expression, particularly in vulnerable brain regions that are also deprived of estrogen protection [64, 65]. However, clinical trials using hormone replacement therapy (HRT) and selective estrogen receptor modulators (SERM) to mimic the neuronal protective activity of estrogen in $A D$ patients were unsuccessful and were abandoned due to the side effects. Factors, such as age, basal cognitive activity, genetic background of the patients, disease stage, and duration of treatment were different among patients and likely contributed to the failure of HRT and SERM treatment [23, 63-65]. When the reasons of this failure were studied at the cellular level, local estrogens and aromatase were also found to be responsible [66]. Studies in hippocampal brain slices have revealed that local concentration of estrogen is six times higher than serum concentration [67]. Neuronal estrogen receptor (ER) expression 
is known to be mediated by local estrogen synthesis, and neuronal estrogen can only be provided by local aromatase activity. When local aromatase expression and, therefore, local estrogen synthesis is inhibited, neuronal $E R$ expression and the protective effect of estrogen disappear, regardless of how much estrogen is given exogenously [67].

These reports suggest that estrogen can only be neuroprotective if sufficient estrogen levels are present in the brain before morphological changes, such as $A \beta$ plaque formation, occur in $A D$. Therefore, estrogen treatment could prevent or slow down the development of $A D$. Once the brain has been deprived of estrogen for an extended time, the protective effect no longer occurs, and subsequent hormone treatment might even be detrimental to cognition $[66,67]$.

\section{Seladin-1 and Brain Physiology and Pathology}

Studies to investigate the causes of $A D$ have resulted in the discovery of a new protein approximately 20 years ago by Greeve [68] using a differential mRNA display approach. This approach identified a novel gene, named seladin-1, the abbreviation for Selective Alzheimer's Disease indicator-1, which was differentially expressed in selective vulnerable brain regions of $A D$ patients, such as the hippocampus, amygdala, inferior temporal cortex, and the entorhinal cortex. Down-regulation of seladin-1 expression in these areas was paralleled by increased hyperphosphorylated tau, a protein component of neurofibrillary tangles, and neurodegeneration [68-72].

A later study showed that this protein is actually a well-known enzyme, 3-betahydroxysterole delta-24-reductase, that is encoded by the DHCR24 gene and was identified as a human homolog of the DIMINUTO/DWARF1 gene described previously in plants [73]. Seladin-1/DHCR24 is highly conserved and expressed in the CNS, especially in neurons under basal conditions [70]. It catalyzes the last step in the biosynthesis of cholesterol from desmosterol [74]. The deficiency of seladin-1/DHCR24 has been shown to decrease cholesterol levels in the plasma membrane and subsequently, reduce the formation and stability of lipid rafts [75] Thus, as lipid rafts are important for mediating cell function [76] downstream cellular signaling is also affected [68]. Seladin-1/DHCR24 has also been reported to play a role in cellular responses against oxidative and oncogenic stress and inflammation [77-82]. Independent from its enzymatic activity, seladin-1 protein has been shown to protect neurons exposed to $A \beta$ and oxidative stress from apoptotic cell death [70] and inhibit caspase- 3 activity responsible for apoptosis [83].

Recently, the interactions between seladin-1 and estrogen were investigated. Fetal neuroepithelial cell (FNC) cultures were used to study the relationship between seladin-1 and estrogen. These cells synthesize ERa and $\beta$, as well as seladin-1. An increase in seladin-1 mRNA was observed in these cells after treatment with $17 \beta-E 2$ and the SERM, tamoxifen. Again, a significant increase in seladin-1 expression was detected after FNC treatment with a selective ERa agonist. These investigators also questioned whether there is an estrogen response element (ERE) on the seladin-1 gene and they identified a possible binding site on the seladin-1 promoter. ERa and the seladin-1 promoter was co-transfected to these cells. Treatment of the cells with $17 \beta$ $E_{2}$ and SERM resulted in seladin-1 luciferase activity proved that seladin-1 gene has ERE. These studies also indicated that seladin-1 is a downstream mediator of the neuroprotective activity of estrogen [69].

In our study, the aromatase inhibitor, letrozole, increased seladin-1 protein levels significantly in human neuroblastoma cells ( $\mathrm{SH}-$ SY5Y). It is known that a decrease in brain $E_{2}$ levels is perceived as stress by neurons, and that brain aromatase levels increase as a protective/ compensatory mechanism [19]. For this reason, we hypothesized that after aromatase inhibition, seladin-1 levels are also increased as a protective mechanism to compensate for the decline in $E_{2}$ synthesis. To test this hypothesis, we measured the $\mathrm{E}_{2}$ level in SH-SY5Y cells and observed that it was significantly decreased in the letrozole-treated group. Thus, increased seladin-1 can trigger an incremental change in cholesterol, the precursor for $E_{2}$ synthesis [84]
(Fig. 3).

Seladin-1 is also important in the synthesis of cholesterol, which contributes to cell membrane structure and barrier properties $[15,68,75,76]$. Studies in rat adrenal gland cells (PC12), SH-SY5Y cells, and FNCs show that seladin-1 protects membrane integrity, which provides resistance to $A \beta$ toxicity [85]. When seladin-1 is silenced, the integrity of the membrane is disturbed, resulting in the formation of $\mathrm{Ca}^{2+}$-permeable pores on the membrane and subsequent cytotoxicity due to $\mathrm{Ca}^{2+}$ hyperexcitation [85]. Seladin-1 overexpression has been shown to prevent this damage by preserving membrane integrity $[15,68,75,76]$. When seladin-1 is knocked out, the integrity of the membrane deteriorates, making easier for $\beta$-secretases (BACE) to break down amyloid precursor protein (APP) into $A \beta$, thereby inhibiting plasmin, the enzyme that degrades $A b s$, and causing $A \beta$ accumulation $[15,68,75,76]$.

In seladin-1 knock-out (SelKO) mouse models, homozygous mice were found to be born with severe dermopathies and die shortly after birth, so experiments are performed using heterozygous mice. AD mice were crossed with SelKO mice (AD/SelKO) in order to mimic the decreased expression of seladin-1 in $A D$; the membrane and intracellular cholesterol levels were decreased, and desmosterol levels were increased in the $A D /$ SelKO mice. Significant $A b_{1-40}$ and $A \beta_{1-42}$ increases were also observed in $A D /$ SelKO mice compared to that in the $A D$ mice [75].

In individuals with desmosterolosis, a rare congenital anomaly in humans, there is a significant decrease in seladin-1 enzyme activity due to gene mutations, and serious neurophysiological changes and developmental anomalies are seen [86].

Seladin-1 also plays an important role in nerve protection, similar to aromatase, via its essential enzymatic activity [71, 72]. It is not a coincidence that expression of both aromatase and seladin-1 enzymes, especially in brain regions sensitive to $A D$, are found to be reduced. Another common feature of these enzymes is an increase in their expression as an acute response to neurodegenerative injury. 
Brain aromatase and seladin-1 expression and interactions in AD $A D$, the major cause of dementia, is a progressive neurodegenerative disorder that is characterized by memory loss and cognitive deficits with both genetic and environmental components [23, 70, 87]. Reduced serum estrogen in postmenopausal women has been widely reported to increase the risk of $A D$ and is correlated with AD-related neuropathological changes [88-90].

The neuroprotective effects of the aromatase product $E_{2}$ are well established in preclinical studies $[63,91]$. Although in vitro research demonstrated the neurotrophic, neuroprotective [92, 93], neuroregenerative, anti-inflammatory [94, 95], anti-excitotoxic [96], and antioxidant [90, 97, 98] effects of estrogen, the data obtained from clinical studies are conflicting $[89,92,97,99-106]$ in neurodegenerative diseases, such as AD. Early trials supported the idea that patients with $A D$ could benefit from estrogen therapy by improving deficits in memory and cognitive functions; however, these studies were conducted on perimenopausal women or healthy postmenopausal women [106]. In addition, several trials suggested that estrogen therapy can be effective in preventing $A D$ if the therapy is implemented at earlier ages [99-106].

It has been shown that estrogen therapy, HRT, could protect at least some postmenopausal women against cognitive impairment, dementia and $A D$, if the hormone treatment commenced soon after menopause; a later start of HRT may be detrimental [107111]. This would concur with the hypothesis of the "healthy cell bias of estrogen action" [112]. Another important factor that could define subgroups of women for potential estrogen therapy is genetic. Polymorphisms related to gonadal steroid synthesis and metabolism could affect the outcomes of HRT. Therefore it is likely that certain variants of the aromatase gene may be associated with the risk of $A D$ in women. It has also been shown that CYP19 polymorphisms affect the risk of $A D$ in women. Indeed, CYP19 gene variants could potentially affect the risk for $A D$ by reducing or increasing the conversion of androgens into estrogens, resulting in altered protection against neuronal

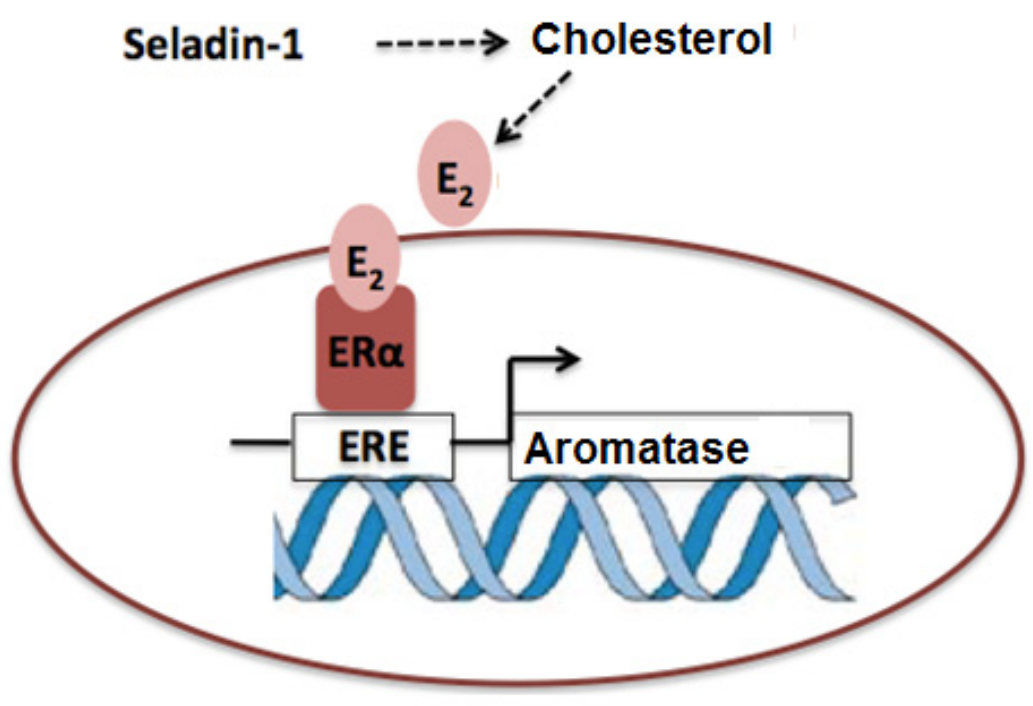

Figure 3. Schematic of the interaction between aromatase and seladin-1. Decrease in brain $\mathrm{E}_{2}$ levels is perceived as stress by neurons, and brain aromatase levels increase as a protective/compensatory mechanism [19]. After aromatase inhibition, seladin-1 levels increased as a protective mechanism to compensate for the decline in $E_{2}$ synthesis. Then, $E_{2}$ binds the estrogen response element (ERE) on the aromatase gene and regulates the aromatase promoter for neuroprotective activity of estrogen [69].

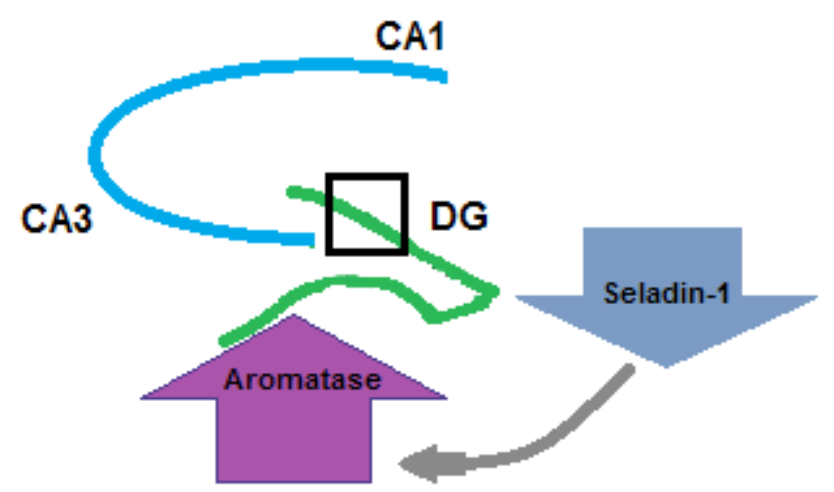

Figure 4. Schematic for the increased aromatase in the DG region of male SelKO/AD mice. Aromatase immunoreactivity in neurons increased significantly in the dentate gyrus (DG) region of male SelKO/AD mice compared to $\mathrm{Sel}^{+} / \mathrm{AD}$ (control) mice. Thus, we speculated that aromatase levels may increase either to improve neurogenesis in the DG or as a result of neurogenesis after seladin-1 gene expression downregulation in $A D$

injury or neurodegeneration through multiple mechanisms [108]. As a result, alterations to plasma estrogen levels cannot always reflect the changes occurring in the CNS, and, despite its protective effect in vitro, exogenous estrogen treatment may not have a therapeutic effect $[19,99,108]$. Therefore, the protective effect of local estrogen may be dominant in the brain, rather than plasma estrogen, and the importance of local brain aromatase expression and activity is emphasized as the source of $E_{2}$ in the brain $[18,42,89,106,109]$.

In humans, sex differences in the development of $A D$ are frequently discussed; for example, the prevalence and severity of $A D$ and the rate of decline is higher and cognitive 
deterioration is faster and more pronounced in women than in men $[110,111]$. In general, the strong decline of circulating $E_{2}$ due to menopause is assumed to be a major risk factor for AD in women [63]. Neuroprotective effects of estrogen, an increased risk of dementia after menopause, and a $19-29 \%$ higher prevalence of $A D$ in women compared to men stimulated an investigation into the relationship between estrogen, the estrogen-synthesizing enzyme aromatase, and AD [64, 65, 108, 112, 113].

In 3-month-old female 5XFAD mice, a significant decrease was observed in total aromatase expression, which was accompanied by reduced aromatase protein level in the $C A 1$ and $C A 3$ regions. It is possible that the increased production of $A \beta$ inhibits aromatase expression in the young mice, which, in turn, results in the loss of neuroprotection by $E_{2}$ [91]. This finding indicates that the function of brainderived aromatase differs between male and female animal models as well.

Furthermore, a transgenic mouse model for AD (APP23 mice), in which the animals develop $A \beta$ plaques and other pathological changes observable in the brains of $A D$ patients $[114$, 115], was crossbred with aromatase- $\mathrm{KO}\left(\mathrm{Ar}^{--}\right)$ mice to test the influence of $E_{2}$ on the formation of $A \beta$ plaques. The resulting female progeny, which is $\mathrm{Ar}^{+/-}$and therefore $\mathrm{E}_{2}$-haploinsufficient, demonstrated faster and more severe $A \beta$ plaque formation and less effective $A \beta$ clearance than did aromatase-expressing APP23 mice [89]. Ovariectomy of APP23 females, i.e., the elimination of their major source of systemic $E_{2}$, did not mimic the effects of genetically-induced aromatase deficiency that affected all aromatase-expressing tissues, including the brain. These results suggest that brain-derived $E_{2}$, rather than ovary-derived $E_{2^{\prime}}$ counteracts $A \beta$ plaque formation and is, therefore, neuroprotective in female mice. Surprisingly, compared with APP23/ $\mathrm{Ar}^{+/+}$mice, $A \beta$ plaque production is reduced in male $\mathrm{APP} 23 / \mathrm{Ar}^{+/-}$mice, suggesting that endogenous testosterone may protect against $A D$ in males and that the neuroprotective role of brainderived $\mathrm{E}_{2}$ may be sex-dependent [116].

Moreover, in order to investigate interactions between aromatase and seladin-1, we used 5XFAD mice crossed with ArKO or SelKO mice.
Using immunohistochemical analysis, we observed that aromatase immunoreactivity in neurons increased significantly in the dentate gyrus (DG) region of male SelKO/ $A D$ mice compared to Sel ${ }^{+} / A D$ (control) mice. Furthermore, we also observed that $E_{2}$ levels increased in this group, whereas a significant decrease was observed in the ArKO group. Aromatase increases in the DG of 14-16-weekold SelKO/AD male mice, during the earlier stages of $A D$ [84]. In $A D$, the aromatase level may increase at earlier stages as a protective mechanism against neurodegeneration. Similar results were observed in vitro when serum, the cholesterol source, was removed from cell culture media [42], and in vivo as a compensatory response to acute neurotoxin administration [117-119]. It is tempting to assume that an ADrelated increase in aromatase expression, and therefore, a potential increase in $E_{2}$ synthesis, represents a protective reaction of the tissue to early stages of the developing disease [91]. Furthermore, the alteration of aromatase levels, especially in the DG, can be associated with the role of the DG in neurogenesis [120]. Thus, we speculated that aromatase levels may increase either to improve neurogenesis in the DG or as a result of neurogenesis after seladin-1 gene expression downregulation in AD (Fig. 4). The reason why aromatase increase did not occur in female SelKO/AD mice was not apparent, in contrast to male mice, but may be due to the compensatory effect of higher peripheral estrogen against decreased brain estrogen in these non-ovariectomized young female mice. Brains of SelKO/AD male mice may need more local aromatase and estrogen expression to compensate for less peripheral estrogen, caused by the deprivation of the protective effects of gonadal estrogen relative to females, and the lack of the neuroprotective effects of seladin-1. We suggested that the CNS response to neurodegeneration is reflected as an increase in the local aromatase level. Therefore, the aromatase level does not increase in SelKO/ $A D$ female mice because the neuroprotective effect of peripheral estrogen compensates for the changes in local estrogen expression [84] In women, decreases in gonadal estrogen and local aromatase expression may help to explain their vulnerability to neurodegenerative events and the increase of $A D$ diagnoses after menopause. The sex differences found in the mouse model are in agreement with previous findings, which indicate that the neuroprotective role of brain-derived $\mathrm{E}_{2}$ may be more important in females than in males [89, $113,116]$, and may help to explain why women are more prone to $A D$ than men $[91,110]$.

\section{Aromatase in stroke}

Several studies have shown that $A D$ and ischemic brain injury share similar neuropathological features, including altered APP processing, $A \beta$ accumulation [121-126], and increased neuroinflammation [127]. Cerebral ischemia or "ischemic stroke" is caused by advanced age, hypertension, previous history of stroke or a transient ischemic attack, cardiac arrest, traumatic brain injury, diabetes, cigarette smoking, atrial fibrillation and high cholesterol [128], and results in neuronal death predominantly in brain regions that are most intrinsically vulnerable, such as the CA1 region of the hippocampus [129].

Estrogens display neuroprotective properties and promote neural regeneration after traumatic brain injury and cerebral ischemia by decreasing apoptotic signaling, neuroinflammation, and oxidative stress and by normalizing glutamate concentrations [130]. Aromatase expression increases following brain trauma, suggesting that aromatase plays an important role in neuroprotection by increasing local estrogen levels [23]. These neuroprotective effects of estrogen during brain ischemia have been well-established in ovariectomized rodents and result in a significant decrease in the lesion size and infarct volume $[13,130,131]$.

Aromatase plays an important role in endogenous $E_{2}$-mediated protective mechanisms and presents a novel target for neuroprotective therapy in ischemic pathology [19]. Female ArKO mice have significantly increased ischemic damage induced by reversible MCAO in all areas of the examined brain compared to wild-type littermates. The same result was observed when $E_{2}$ production was pharmacologically inhibited by an aromatase inhibitor, fadrozole [19]. Aromatase protein increased after MCAO, and 
studies evaluating the peri-infarct location and astrocytic localization implicate the potential for aromatase to promote the survival of cells in the penumbra after experimental stroke by local synthesis of estrogens [41]. Peterson et al. (2001) have shown that aromatase mRNA and protein are rapidly and locally upregulated in RGCs, and that these cells migrate to injury sites following neural damage in zebra finch brains. These findings suggest that injury-dependent upregulation of aromatase may be a conserved characteristic of the vertebrate brain and an important component of the initial response of neural tissue to injury [40].

In addition to aromatase expression, transcription of the C/EBP $\beta$ protein, a well-known mediator of injury and inflammatory responses in peripheral tissues [132] and potentially, in the brain $[133,134]$, is increased in ischemic hippocampi and decreased after treatment with the aromatase inhibitor, megestrol acetate. We speculate that, because aromatase is a gene associated with regeneration, it is likely to be a direct transcriptional target of the C/EBP family [135].

Moreover, altered lipid metabolism is also believed to be a key event that contributes to CNS injuries, such as stroke [136, 137]. SREBP-1 is a transcription factor best known for regulating lipid and cholesterol metabolism. The active fragment of SREBP is transported to the nucleus where it binds to the promoters of SREBP target genes, most of which are involved in the synthesis and metabolism of lipids [138]. A recent study reported that, while the detailed mechanisms by which SREBP-1 activation leads to neuronal cell death remain to be established, the researchers discovered a method to inhibit SREBP-1 and, thereby, significantly reduce cell death [139]. In addition, another study showed that the removal of fetal bovine serum, a source of cholesterol, from cell medium results in increased astrocytic aromatase expression and activity [140]. We also observed an increase in aromatase expression when the serum was removed from neuronal cell cultures, and $A \beta$ inhibited this aromatase induction. It is known that $A \beta$ forms lipid micelles in cell culture and, therefore, we speculated that these $A \beta$-lipid micelles blocked the transfer of SREBP-1 to the active form, produced a false signal that prevented aromatase expression, and blocked the protective increase of aromatase in stress conditions [141]. Moreover, we investigated the effects of indinavir, an inhibitor of nuclear SREBP localization, on the expression of aromatase in rat hippocampi after transient global ischemia. Aromatase and nuclear SREBP-1 protein levels significantly increased after transient global ischemia in the rat hippocampi, and this increase was reduced by indinavir treatment [141]. Taghibiglou et al. (2009) found that SREBP-1 activity increased during oxygen and glucose deprivation, conditions that mimic ischemic stroke, in neuronal cells, and that this activation was blocked by N-methyl-D-aspartate receptor (NMDAR) antagonists. One study also reported that SREBP-1 was activated in a mouse model of ischemic stroke and this activation in affected neurons was an essential step for NMDAR-mediated excitotoxic neuronal death. Inactivation of the SREBP-1 pathway was shown to reduce neuronal damage after stroke in mice [139]. Moreover, another report suggests that the excitatory receptor-dependent activation of SREBP-1 promotes neuronal cell death [142]

Our conclusions from these studies support the central hypothesis that the upregulation of aromatase in ischemic hippocampi and its downregulation in megestrol acetate-treated and indinavir-treated tissues may partly depend on transcription factors, such as C/EBP $\beta$ [135] and SREBP-1 [141], respectively. Our findings indicate that ischemia, as well as chronic neurodegenerative processes, lead to increased cytoplasmic aromatase and nuclear C/EBP $\beta$ and SREBP-1. Thus, it is possible to hypothesize an interaction between this enzyme and transcription factors $[135,141]$.

Interestingly, clinical and experimental findings after stroke are abundant and highlight important sex differences [143, 144]. Clinical studies showed that aging women display worse outcomes following an ischemic stroke than men, and that women also have higher mortality after hemorrhagic strokes [145]. In addition, rodents ischemic stroke models demonstrate that young females have smaller infarcted area than young males [146] and that they exhibit less severe stroke consequences during proestrus (high $17 \beta-E_{2}$ concentration) than during metestrus (low $17 \beta-E_{2}$ concentration) [147].
During aging, mortality is higher in females than in males, and males display greater bleeding and mortality during hemorrhagic strokes [145]. The study also showed that estrogen treatments improve outcomes in young females and males after ischemic and hemorrhagic strokes, although their effects in aging females during ischemia are controversial [145]. Other clinical and experimental findings also document the impact of sex and sex steroids in other CNS insults $[148,149]$.

\section{Seladin-1 in Stroke}

A previous study showed that APP and $A \beta$, or their fragments, aggregate in dense plaquelike deposits in the thalamus of rats subjected to transient MCAO [150]. Subsequently, it was demonstrated that APP processing and the expression of $A \beta$-degrading enzymes are altered in the ipsilateral thalamus following MCAO, and that this damage remains long after the initial ischemic insult [151]. These alterations coincided with significantly augmented $\mathrm{Ca}^{+2}$ levels, depletion of BACE trafficking proteins and increased BACE activity in the ipsilateral thalamus. Based on these findings, the observed alterations resulting in $A \beta$ accumulation could be linked to disrupted $\mathrm{Ca}^{+2}$ homeostasis. A nonselective $\mathrm{Ca}^{+2}$ channel blocker, bepridil, inhibits BACE-mediated APP cleavage in vitro and in vivo [152-154] and significantly decreased $\mathrm{Ca}^{+2}$ levels [155]. This decrease was strongly correlated with reduced $A \beta_{42}$ and $A \beta_{40}$ levels in the ipsilateral thalamus of MCAO rats. Seladin-1 decreased at both mRNA and protein levels after MCAO; conversely, bepridil treatment restored seladin-1 expression in the ipsilateral thalamus of MCAO rats and was associated with the improved neuronal survival [156]. The seladin-1 protein is encoded by the $D H C R 24$ gene and is a potential neuroprotective factor. This notion stems from previous studies, which showed that seladin-1 plays a cytoprotective role in oxidative stressinduced apoptosis by scavenging reactive oxygen species [83]. Moreover, seladin-1 interacts with the $\mathrm{p} 53$ tumor suppressor protein [77], a redox-sensitive transcription factor involved in the pathogenesis of brain ischemia and AD. Importantly, seladin-1 expression is downregulated in large pyramidal neurons in specific regions in $A D$ brain and suggests that 
seladin-1 is associated with selective neuronal vulnerability [68-72].

From this evidence, it seems reasonable to speculate that neuronal damage accompanied by a reduction in seladin-1, similar to reports in certain $A D$ brains, will have important consequences in the CNS response to ischemia. Thus, paucity in seladin-1 could affect the amount of damage and time of recovery from ischemia, as it is highly dependent on the amount of stress to the affected area [82].

Recently, Sel+/- and wild-type (WT) mice were subjected to permanent MCAO. Selt/mice displayed larger infarct volumes after MCAO than their WT littermates. Moreover, treatment of WT mice with the seladin-1 inhibitor, U18666A, increased ischemic lesions. Inflammation related mediators, such as COX2, iNOS, TNF-a, and IL-10, were increased after ischemia in Sel+/- mice, compared with WT counterparts [82].

\section{Brain aromatase and seladin-1 in epilepsy.}

Epilepsy is the most common serious neurological disease and is defined as "a disease of the brain characterized by an enduring predisposition to generate epileptic seizures" [157]. Epilepsy, antiepileptic drugs (AEDs), and the reproductive system exhibit complex mechanisms of action. Reproductive endocrine and sexual dysfunction are more common in patients with partial epilepsy than in those with generalized epilepsy [157-167], particularly in temporal lobe epilepsy that affects the limbic system, because this area is extensively interconnected with the hypothalamic nuclei that regulate gonadal function [168-170]. This region controls gonadal hormones, including estrogen, which is converted from testosterone by aromatase. Patients with temporal lobe epilepsy have higher aromatase activity in the cerebral cortex than in subcortical areas. Inhibition of cerebral aromatization results in lower focal availability of estrogen and, theoretically, improves seizure control [171]. While the increase in aromatase expression, and, thus, the synthesis of estrogen, in head trauma, ischemia and $A D$ are neuroprotective, the effects of estrogen on epilepsy are complex. A recent study established that estrogens are epileptogenic [172] and have proconvulsive effects [173]. This effect is due to the ability of estrogens to lower the seizure threshold thereby increase seizure discharges [172, 174], and to increase neural membrane excitability $[173,175]$. However, there have also been some studies that hint at a potential anticonvulsant role of estrogen [175], highlighting not only the complex role of gonadal hormones in the body but also the complex etiology of epilepsy itself. Thus, $E_{2}$ has mixed effects, ranging from no effect, mild anticonvulsant to proconvulsant effects, on seizures that depend on whether physiological or supraphysiological doses have been used [176]. In that sense, aromatase enzyme inhibitors may have great potential for use as an antiepileptic treatment [177]. In some clinical trials, aromatase inhibitors have been used to treat prostate hypertrophy; some success was reported in men with complex partial epilepsy treated using this drug and other aromatase inhibitors [178-180]. In fact, letrozole, approved for the treatment of breast cancer by the Food and Drug Administration (FDA) [181], has been clinically successful in treating epilepsy in men [178]. In a case study, a 61-year-old man with temporal lobe epilepsy and sexual dysfunction due to low testosterone levels used letrozole to normalize his testosterone level and improve his sexual function and seizure control [178, 180]. Therefore, testosterone supplementation, concomitant aromatase inhibitors [182], and AEDs with aromatase-inhibiting properties should be further investigated as a beneficial treatment for male patients with epilepsy [161$163,177,178,185-187]$

Therefore, twelve AEDs were tested on commercially available microsomes, from transfected insect cells, for their ability to inhibit aromatase using dibenzylfluorescein as a substrate. The drugs inhibiting aromatase were: lamotrigine, oxcarbazepine, tiagabine, phenobarbital, phenytoin, ethosuximide, and valproate. Gabapentin, primidone, topiramate, and vigabatrin showed no inhibition [177]. Most therapies, apart from inhibiting aromatase, are based on estrogen-lowering drugs and act via various mechanisms, such as linking estrogens to globulins (carbamazepine) [158] binding to estrogen receptors (neurontin and gabapentine-2-[1-(aminomethyl)cyclohexyl] acetic acid), or by inhibiting steroid sulfatase activity (topiramate-sulphamate). These studies suggest that the molecular mechanisms of AEDs are related to either steroid binding or synthesis. Enzyme-inducing AEDs, such as phenobarbital, phenytoin, and carbamazepine, can directly suppress gonadal testosterone synthesis [186], increase hepatic synthesis of sex hormone-binding globulin (SHBG) [187], and increase serum $E_{2}$ levels, either in absolute concentrations or relative to bioavailable testosterone (BAT), and are associated with hyposexuality and hypogonadism [188, 189]. Therefore, a small increase in $E_{2}$ level, presumably as a result of an AED-induced aromatase activity increase, could have a disproportionately large negative feedback effect and contribute to hypogonadism [190].

The effects of AEDs on aromatase and the expression level of its coding gene CYP19 were examined in the liver, but not in the brain or gonads [191]. Therefore, we investigated the possible effects of the highly efficient, newgeneration, antiseizure/anticonvulsant drug, levetiracetam (LEV), on central and gonadal aromatase expression and gonadal tissue functionality. Epileptogenesis was generated in male Wistar rats by an intraperitoneal injection of the excitotoxic agent kainic acid (KA). Significant decrease in the average spike number, amplitude, and frequency by electroencephalography (EEG) were observed in KA-treated rats that received an extrapolated dose $(27 \mathrm{mg} / \mathrm{kg} /$ day) of LEV from a clinically used human dose $(1000 \mathrm{mg} / 75$ $\mathrm{kg}$ adult) at all time points when compared to the first day of the experiment. LEV did not affect seladin-1 expression levels in the brains of male rats, suggesting that increases in KA-induced neurosteroidogenic enzyme expression were specific to aromatase. Our study indicates that LEV exerts a slight inhibitory effect on basal central aromatase and attenuates testicular aromatase [185]. These results also correlate with a significant downregulation of CYP19 in H295R cells exposed to LEV at intermediate $(100 \mu \mathrm{M})$ and high $(175 \mu \mathrm{M})$ concentrations in vitro [192]. LEV decreases aromatase levels in the testis and increases the seizure threshold, possibly by decreasing systemic $E_{2}$ levels. LEV does not induce testicular aromatase, affect the contractility function of the vas deferens, or 
induce significant changes to the histology of male gonadal tissues. Therefore, these may partly explain why LEV does not cause reproductive dysfunction. LEV may produce a central alteration in the testosterone/estrogen ratio by decreasing the expression of brain and gonadal aromatase. Furthermore, we suggest that the effects of the antiseizure drugs on central and testicular aromatase may be investigated to determine if they may be beneficial for treating male patients with epilepsy [185].

It has also been suggested that $E_{2}$ enhances neuronal excitability in the hippocampi of male but not female rats [176]. However, contrary to these conclusions, AEDs and epilepsy are often associated with sexual disorders in women as well, such as in hyperandrogenism, menstrual disorders, and ovarian cysts. Patients with epilepsy often show hormonal abnormalities, which may be caused either by epilepsy or by continuous treatment with AEDs [158]. Among women, the relationship between epilepsy and estrogen imbalance is especially striking. For example, it has been shown that approximately $56.5 \%$ of women with amenorrhea or anovulatory cycles have EEG abnormalities [172]. Seizure frequency can also be associated with perimenarche, menarche [172, 173], menstruation [172-174, 193], pregnancy [172, 173], perimenopause [172-174, 193], and menopause [172-174, 193]. Catamenial epilepsy, a form of epilepsy in which the periodicity of seizure exacerbation corresponds closely with the menstrual cycle, is thought to affect between $30 \%$ to $70 \%$ of epileptic females [172-174, 193]. However, the periodicity of seizures is common among both sexes $[174,177]$.

The use of aminoglutethimide, a firstgeneration aromatase inhibitor, has been attempted as an antiepileptic drug in combination with other standard drugs [194]. Letrozole is a third-generation, reversible, nonsteroidal aromatase inhibitor, that was approved by FDA for the treatment of postmenopausal women with hormone receptor-positive or hormone receptorunknown locally advanced and metastatic breast cancer [195]. A recent preclinical study demonstrated the protective effect of letrozole in preventing kindling induced by pentylenetetrazole (PTZ) in mice [196]. Moreover, letrozole was previously reported to inhibit the testosterone-induced increase in PTZ seizure activity in mice [197]. Letrozole administration prior to KA significantly increased the latency to onset of seizures and reduced seizure occurrence in mice. However, the drug demonstrated no discernible effects on KA-mediated neurotoxicity [6].

It is interesting to note that letrozole is easily transported across the blood-brain barrier after systemic application and exerts an inhibitory influence on hippocampal estrogen synthesis, as it does in other regions of the body in mice [198]. Therefore, it was shown that systemic and local inhibition of aromatase activity by letrozole causes spine synapse loss and significantly impairs (long term potentiation) LTP in the hippocampus of female and ovariectomized mice, but not in male mice. Thus, ovariectomy itself does not influence LTP, and all evidence points to a role of hippocampus-derived estrogen, rather than to a role of estrogen from peripheral sources, for the LTP. In this context, it is useful to consider that testosterone is also neuroprotective in the male brain [199] after letrozole treatment since testosterone is the direct substrate of aromatase [200].

A case report of a 61-year-old woman with long-standing epilepsy, since age 19 , with an average seizure frequency of 5-8 per month (93/year; range 83-142/year) and a diagnosis of post-menopausal breast cancer at the age of 56, had halved her seizure frequency to an average of $<4$ per month. Replacing tamoxifen with exemestane, an aromatase inhibitor, resulted in complete abolition of seizures, and the patient has remained seizure-free for over 4 years. This suggests that aromatase inhibitors may be beneficial as a mono-therapy or an adjuvant for the treatment of epilepsy, and further research in this area is warranted [171]. Computer-based pharmacophore searches using a model based on aromatase inhibition and the enzyme's structural features can be used to screen for new candidate antiepileptic therapies. In fact, potent aromatase inhibitors and current antiepileptic compounds display significant (over 70\%) chemical and structural similarity, and similarity analyses have proposed a number of antiepileptic compounds with a high potential for aromatase inhibition [177].

\section{Conclusion}

The identification of the brain-specific aromatase promoter and the activity of local estrogen through ERa and its downstream regulator, seladin-1, propose these enzymes to be new targets in drug design for the treatment of neurodegenerative diseases, such as $A D$, stroke, and epilepsy.

Thus, therapeutic approaches that enhance aromatase activity may be targeted to promote neuroprotection in neurodegenerative diseases. Furthermore, systemic delivery of steroidal hormones, such as estrogen, for their neuroprotective effects have some potential risks, such as breast and ovarian cancer. Therapeutic approaches that are alternative to systemic steroid administration will highlight the neuroprotective effects of these steroids and will be advantageous in neuroprotection.

In conclusion, centrally produced gonadal steroids exert numerous actions, including neuroprotection, constitutive expression of estrogen and regeneration.

Conflict of interest: Authors state no conflict of interest

\section{Acknowledgements}

We thank Prof. Orhan Oz (University of Texas Southwestern, Dallas, TX, USA) for providing the ArKO mice and Prof. Evan Simpson (Hudson Institute of Medical Research, Australia) for giving us permission to use these mice.

Our study was funded by the Scientific and Technological Research Council of Turkey (112S135), the Hacettepe University Research Foundation, Project No: 0202301009 and 01001301 001-215), and by grants from the Swedish Medical Research Council (project no 05817), Stiftelsen for Gamla Tjanarinnor, Stohnes Foundation and Swedish Alzheimer Foundation.

We also thank the Technology Transfer Center of Hacettepe University for supporting the advance editing of the manuscript. 
[1] Biagini G, Panuccio G, Avoli M. Neurosteroids and epilepsy. Curr Opin Neurol. 2010;23(2):170-6.

[2] Reddy DS, Mohan A. Development and persistence of limbic epileptogenesis are impaired in mice lacking progesterone receptors. J Neurosci. 2011;31(2): 650-8.

[3] Gangisetty O, Reddy DS. Neurosteroid withdrawal regulates GABA-A receptor alpha4-subunit expression and seizure susceptibility by activation of progesterone receptor-independent early growth response factor-3 pathway. Neuroscience. 2010;170(3):865-80.

[4] Pereira M Jr, Soares JM Jr, Valente SG, Oliveira PB, Cavalheiro EA, Amado $D$, et al. Estrogen effects on pilocarpine-induced temporal lobe epilepsy in rats. Maturitas. 2009;62(2):190-6.

[5] Frye CA, Ryan A, Rhodes M. Antiseizure effects of 3 alphaandrostanediol and/or 17 beta-estradiol may involve actions at estrogen receptor beta. Epilepsy Behav. 2009;16(3):418-22.

[6] Iqbal R, Jain GK, Siraj F, Vohora D. Aromatase inhibition by letrozole attenuates kainic acid-induced seizures but not neurotoxicity in mice. Epilepsy Res. 2018;143:60-9.

[7] Bjorkhem I, Lütjohann D, Breuer O, Sakinis A, Wennmalm A. Importance of a novel oxidative mechanism for elimination of brain cholesterol. Turnover of cholesterol and 24(S)-hydroxycholesterol in rat brain as measured with 1802 techniques in vivo and in vitro. J Biol Chem. 1997;272(48):30178-84.

[8] Mauch DH, Nägler K, Schumacher S, Göritz C, Müller EC, Otto A, et al. CNS synaptogenesis promoted by glia-derived cholesterol. Science. 2001; 294(5545):1354-7.

[9] Do Rego JL, Seong JY, Burel D, Leprince J, Luu-The V, Tsutsui K, et al. Neurosteroid biosynthesis: enzymatic pathways and neuroendocrine regulation by neurotransmitters and neuropeptides. Front Neuroendocrinol. 2009;30(3):259-301.

[10] Linetti A, Fratangeli A, Taverna E, Valnegri P, Francolini M, Cappello V, et al. Cholesterol reduction impairs exocytosis of synaptic vesicles. J Cell Sci. 2010; 123(Pt 4):595-605.

[11] Liu JP, Tang Y, Zhou S, Toh BH, McLean C, Li H. Cholesterol involvement in the pathogenesis of neurodegenerative diseases. Mol Cell Neurosci. 2010; 43(1):33-42.

[12] Zhang J, Liu Q. Cholesterol metabolism and homeostasis in the brain. Protein Cell. 2015;6(4):254-64.

[13] Diotel N, Charlier TD, Lefebvre d'Hellencourt C, Couret D, Trudeau VL, Nicolau JC, et al. Steroid transport, local synthesis, and signaling within the brain: roles in neurogenesis, neuroprotection, and sexual behaviors. Front Neurosci. 2018;12:84.

[14] Baulieu EE. Neurosteroids: a novel function of the brain. Psychoneuroendocrinology. 1998;23(8):963-87.

[15] Peri A, Benvenuti S, Luciani P, Deledda C, Cellai I. Membrane cholesterol as a mediator of the neuroprotective effects of estrogens. Neuroscience. 2011;191:107-117.

[16] McEwen BS, Woolley CS. Estradiol and progesterone regulate neuronal structure and synaptic connectivity in adult as well as developing brain. Exp Gerontol. 1994;29(3-4):431-6.
[17] McEwen BS, Gould E, Orchinik M, Weiland NG, Woolley CS. Oestrogens and the structural and functional plasticity of neurons: implications for memory, ageing and neurodegenerative processes. Ciba Found Symp. 1995;191:52-73.

[18] Azcoitia I, Sierra A, Veiga S, Honda S, Harada N, Garcia-Segura LM. Brain aromatase is neuroprotective, J Neurobiol. 2001;47(4):318-29.

[19] McCullough LD, Blizzard K, Simpson ER, Oz OK, Hurn PD. Aromatase cytochrome $\mathrm{P} 450$ and extragonadal estrogen play a role in ischemic neuroprotection. J Neurosci. 2003;23(25):8701-5.

[20] Murashov AK, Pak ES, Hendricks WA, Tatko LM. 17beta-Estradiol enhances neuronal differentiation of mouse embryonic stem cells. FEBS Lett. 2004; 569(1-3):165-8.

[21] Mukai H, Kimoto T, Hojo Y, Kawato S, Murakami G, Higo S, et al. Modulation of synaptic plasticity by brain estrogen in the hippocampus. Biochim Biophys Acta. 2010;1800(10):1030-44.

[22] Frick KM, Kim J, Tuscher JJ, Fortress AM. Sex steroid hormones matter for learning and memory: estrogenic regulation of hippocampal function in male and female rodents. Learn Mem. 2015;22(9):472-93.

[23] Garcia-Segura LM. Aromatase in the brain: not just for reproduction anymore. J Neuroendocrinol. 2008;20(6):705-12.

[24] Simpson ER. Aromatase: biologic relevance of tissue-specific expression. Semin Reprod Med. 2004;22(1):11-23.

[25] Bulun SE, Chen D, Lu M, Zhao H, Cheng Y, Demura M, et al. Aromatase excess in cancers of breast, endometrium and ovary. J Steroid Biochem Mol Biol. 2007;106:81-96.

[26] Bulun SE, Lin Z, Imir G, Amin S, Demura M, Yilmaz B, et al. Regulation of aromatase expression in estrogen-responsive breast and uterine disease: from bench to treatment. Pharmacol Rev. 2005;57:359-383.

[27] Kamat A, Hinshelwood MM, Murry BA, Mendelson CR. Mechanisms in tissue-specific regulation of estrogen biosynthesis in humans. Trends Endocrinol Metab. 2002:13(3):122-8.

[28] Simpson ER, Davis SR. Minireview: aromatase and the regulation of estrogen biosynthesis-some new perspectives. Endocrinology. 2001;142(11):4589-94.

[29] Naftolin F, Ryan KJ, Petro Z. Aromatization of androstenedione by the diencephalon. J Clin Endocrinol Metab. 1971;33(2):368-70.

[30] Hill RA, McInnes KJ, Gong EC, Jones ME, Simpson ER, Boon WC. Estrogen deficient male mice develop compulsive behavior. Biol Psychiatry. 2007;61(3): 359-66.

[31] Dalla C, Antoniou K, Papadopoulou-Daifoti Z, Balthazart J, Bakker J. Oestrogen-deficient female aromatase knockout (ArKO) mice exhibit depressive-like symptomatology. Eur J Neurosci. 2004;20(1):217-28.

[32] Kravitz HM, Janssen I, Lotrich FE, Kado DM, Bromberger JT. Sex steroid hormone gene polymorphisms and depressive symptoms in women at midlife, Am J Med. 2006;119(9 Suppl 1):S87-93.

[33] Jenkins V, Shilling V, Fallowfield L, Howell A, Hutton S. Does hormone therapy for the treatment of breast cancer have a detrimental effect on memory and cognition? A pilot study. Psychooncology. 2004;13(1):61-6.

[34] Bender CM, Sereika SM, Brufsky AM, Ryan CM, Vogel VG, Rastogi 
$P$, et al. Memory impairments with adjuvant anastrozole versus tamoxifen in women with early-stage breast cancer. Menopause. 2007;14(6):995-8.

[35] Kretz O, Fester L, Wehrenberg U, Zhou L, Brauckmann S, Zhao S, et al. Hippocampal synapses depend on hippocampal estrogen synthesis. J Neurosci. 2004;24(26):5913-21.

[36] Rune GM, Frotscher M. Neurosteroid synthesis in the hippocampus: role in synaptic plasticity. Neuroscience. 2005;136(3):833-42.

[37] Prange-Kiel J, Rune GM. Direct and indirect effects of estrogen on rat hippocampus. Neuroscience. 2006;138(3):765-72.

[38] von Schassen C, Fester L, Prange-Kiel J, Lohse C, Huber C, Böttner $M$, et al. Oestrogen synthesis in the hippocampus: role in axon outgrowth. J Neuroendocrinol. 2006;18(11):847-56.

[39] Garcia-Segura LM, Wozniak A, Azcoitia I, Rodriguez JR, Hutchison $\mathrm{RE}$, Hutchison JB. Aromatase expression by astrocytes after brain injury: implications for local estrogen formation in brain repair. Neuroscience. 1999;89(2): 567-78.

[40] Peterson RS, Saldanha CJ, Schlinger BA. Rapid upregulation of aromatase mRNA and protein following neural injury in the zebra finch (Taeniopygia guttata). J Neuroendocrinol. 2001;13(4):317-23.

[41] Carswell HV, Dominiczak AF, Garcia-Segura LM, Harada N, Hutchison JB, Macrae IM. Brain aromatase expression after experimental stroke: topography and time course. J Steroid Biochem Mol Biol. 2005;96(1):89-91.

[42] Azcoitia, I., et al., Aromatase expression by reactive astroglia is neuroprotective, Ann. N. Y. Acad. Sci., 2003, 1007, 298-305.

[43] Garcia-Segura LM, Sierra A, Veiga S, Garcia-Segura LM. Aromatase: a neuroprotective enzyme. Prog Neurobiol. 2003:71(1):31-41.

[44] Garcia-Ovejero D, Veiga S, García-Segura LM, Doncarlos LL. Glial expression of estrogen and androgen receptors after rat brain injury. J Comp Neurol. 2002;450(3):256-71.

[45] Azcoitia I, Garcia-Ovejero D, Chowen JA, Garcia-Segura LM. Astroglia play a key role in the neuroprotective actions of estrogen. Prog Brain Res. 2001;132: 469-78.

[46] Kelicen Ugur P, Lule S, Cincioglu M, Pekiner C, Gursoy-Ozdemir Y. Megestrol acetate inhibits the expression of cytoplasmic aromatase through nuclear C/EBPbeta in reperfusion injury-induced ischemic rat hippocampus. Eur J Pharmacol. 2011:654(3):217-25.

[47] Klores M, Moon JT, Duncan KA. Expression of glial CBP in steroid mediated neuroprotection in male and female zebra finches. J Chem Neuroanat. 2017:79:32-7.

[48] Noctor SC, Flint AC, Weissman TA, Dammerman RS, Kriegstein AR. Neurons derived from radial glial cells establish radial units in neocortex. Nature. 2001; 409(6821):714-20.

[49] Weissman T, Noctor SC, Clinton BK, Honig LS, Kriegstein AR. Neurogenic radial glial cells in reptile, rodent and human: from mitosis to migration. Cereb Cortex. 2003;13(6):550-9.

[50] Kriegstein A, Alvarez-Buylla A. The glial nature of embryonic and adult neural stem cells. Annu Rev Neurosci. 2009;32:149-84.

[51] Walters BJ, Alexiades NG, Saldanha CJ. Intracerebral estrogen provision increases cytogenesis and neurogenesis in the injured zebra finch brain. Dev Neurobiol. 2011;71(2):170-81.

[52] Pedersen AL, Brownrout JL, Saldanha CJ. Neuroinflammation and neurosteroidogenesis: Reciprocal modulation during injury to the adult zebra finch brain. Physiol Behav. 2018:187:51-6.

[53] Adolf B, Chapouton P, Lam CS, Topp S, Tannhäuser B, Strähle U, et al. Conserved and acquired features of adult neurogenesis in the zebrafish telencephalon. Dev Biol. 2006:295(1):278-93.

[54] Pellegrini E, Mouriec K, Anglade I, Menuet A, Le Page Y, Gueguen $M M$, et al. Identification of aromatase-positive radial glial cells as progenitor cells in the ventricular layer of the forebrain in zebrafish. J Comp Neurol. 2007;501(1): 150-67.

[55] Marz M, Chapouton P, Diotel N, Vaillant C, Hesl B, Takamiya M, et al. Heterogeneity in progenitor cell subtypes in the ventricular zone of the zebrafish adult telencephalon. Glia. 2010;58(7):870-88.

[56] Kizil C, Kaslin J, Kroehne V, Brand M. Adult neurogenesis and brain regeneration in zebrafish. Dev Neurobiol. 2012;72(3):429-61.

[57] Diotel N, Vaillant C, Kah O, Pellegrini E. Mapping of brain lipid binding protein (Blbp) in the brain of adult zebrafish, co-expression with aromatase B and links with proliferation. Gene Expr Patterns. 2016;20(1):42-54.

[58] Azcoitia I, Sierra A, Veiga S, Garcia-Segura LM. Brain steroidogenesis: emerging therapeutic strategies to prevent neurodegeneration. J Neural Transm (Vienna). 2005;112(1):171-6.

[59] Forlano PM, Deitcher DL, Myers DA, Bass AH. Anatomical distribution and cellular basis for high levels of aromatase activity in the brain of teleost fish: aromatase enzyme and mRNA expression identify glia as source. J Neurosci. 2001;21(22):8943-55.

[60] Peterson RS, Lee DW, Fernando G, Schlinger BA. Radial glia express aromatase in the injured zebra finch brain. J Comp Neurol. 2004;475(2):261-9.

[61] Barron AM, Pike CJ. Sex hormones, aging, and Alzheimer's disease. Front Biosci (Elite Ed). 2012;4:976-97.

[62] Goodman Y, Bruce AJ, Cheng B, Mattson MP. Estrogens attenuate and corticosterone exacerbates excitotoxicity, oxidative injury, and amyloid beta-peptide toxicity in hippocampal neurons. J Neurochem. 1996;66(5):1836-44.

[63] Pike CJ, Carroll JC, Rosario ER, Barron AM. Protective actions of sex steroid hormones in Alzheimer's disease. Front Neuroendocrinol. 2009;30(2):239-58.

[64] Melcangi RC, Panzica G, Garcia-Segura LM. Neuroactive steroids: focus on human brain. Neuroscience. 2011;191:1-5.

[65] Saldanha CJ, Duncan KA, Walters BJ. Neuroprotective actions of brain aromatase. Front Neuroendocrinol. 2009;30(2):106-18.

[66] Hojo Y, Hattori TA, Enami T, Furukawa A, Suzuki K, Ishii HT, et al. Adult male rat hippocampus synthesizes estradiol from pregnenolone by cytochromes P45017alpha and P450 aromatase localized in neurons. Proc Natl Acad Sci U S A. 2004;101(3):865-870.

[67] Chamniansawat S, Chongthammakun S. A priming role of local estrogen on exogenous estrogen-mediated synaptic plasticity and neuroprotection. Exp Mol Med. 2012;44(6):403-11.

[68] Greeve I, Hermans-Borgmeyer I, Brellinger C, Kasper D, Gomez- 
Isla T, Behl C, et al. The human DIMINUTO/DWARF1 homolog seladin-1 confers resistance to Alzheimer's disease-associated neurodegeneration and oxidative stress.J Neurosci. 2000;20(19):734552.

[69] Peri A, Serio M. Estrogen receptor-mediated neuroprotection:The role of the Alzheimer's disease-related gene seladin-1. Neuropsychiatr Dis Treat. 2008; 4(4):817-24.

[70] Selkoe DJ. Alzheimer's disease: genes, proteins, and therapy. Physiol Rev. 2001;81(2):741-66.

[71] Peri A, Serio M. Neuroprotective effects of the Alzheimer's diseaserelated gene seladin-1. J Mol Endocrinol. 2008;41(5):251-61.

[72] livonen S, Hiltunen M, Alafuzoff I, Mannermaa A, Kerokoski P, Puoliväli $\mathrm{J}$, et al. Seladin-1 transcription is linked to neuronal degeneration in Alzheimer's disease. Neuroscience. 2002;113(2):301-10.

[73] Klahre U, Noguchi T, Fujioka S, Takatsuto S, Yokota T, Nomura T, et al. The Arabidopsis DIMINUTO/DWARF1 gene encodes a protein involved in steroid synthesis. Plant Cell. 1998;10(10):1677-90.

[74] Bloch KE. Sterol structure and membrane function. CRC Crit Rev Biochem. 1983;14(1):47-92.

[75] Crameri A, Biondi E, Kuehnle K, Lütjohann D, Thelen KM, Perga S, et al. The role of seladin-1/DHCR24 in cholesterol biosynthesis, APP processing and A beta generation in vivo. EMBO J. 2006;25(2):432-43.

[76] Simons K, Toomre D. Lipid rafts and signal transduction. Nat Rev Mol Cell Biol. 2000;1:31-9.

[77] Wu C, Miloslavskaya I, Demontis S, Maestro R, Galaktionov K. Regulation of cellular response to oncogenic and oxidative stress by Seladin-1. Nature. 2004;432(7017):640-5.

[78] Luciani P, Deledda C, Rosati F, Benvenuti S, Cellai I, Dichiara F, et al. Seladin-1 is a fundamental mediator of the neuroprotective effects of estrogen in human neuroblast long-term cell cultures. Endocrinology. 2008;149:4256-66.

[79] Kuehnle K, Crameri A, Kälin RE, Luciani P, Benvenuti S, Peri A, et al. Prosurvival effect of DHCR24/Seladin-1 in acute and chronic responses to oxidative stress. Mol Cell Biol. 2008;28(2):539-50.

[80] McGrath KC, Li XH, Puranik R, Liong EC, Tan JT, Dy VM, et al. Role of 3beta-hydroxysteroid-delta 24 reductase in mediating antiinflammatory effects of high-density lipoproteins in endothelial cells. Arterioscler Thromb Vasc Biol. 2009;29:877-82.

[81] Zerenturk EJ, Sharpe LJ, Ikonen E, Brown AJ. Desmosterol and DHCR24: unexpected new directions for a terminal step in cholesterol synthesis. Prog Lipid Res. 2013:52:666-80.

[82] Hernandez-Jimenez $M$, Martínez-López $D$, Gabandé-Rodríguez E, Martín-Segura A, Lizasoain I, et al. Seladin-1/DHCR24 is neuroprotective by associating EAAT2 glutamate transporter to lipid rafts in experimental stroke. Stroke. 2016;47(1):206-13.

[83] Lu X, Kambe F, Cao X, Kozaki Y, KajiT, Ishii T, et al. 3beta-Hydroxysteroiddelta24 reductase is a hydrogen peroxide scavenger, protecting cells from oxidative stress-induced apoptosis. Endocrinology. 2008;149(7):3267-73.

[84] Karahan H, Lule S, Kelicen-Ugur P. Aromatase/Seladin-1 interactions in human neuronal cell culture, the hippocampus of healthy rats and transgenic Alzheimer's disease mice. Pharmacology. 2018;102(12):42-52.

[85] Arispe N, Doh M. Plasma membrane cholesterol controls the cytotoxicity of Alzheimer's disease Abeta (1-40) and (1-42) peptides. FASEB J. 2002:16(12): 1526-36.

[86] Waterham HR, Koster J, Romeijn GJ, Hennekam RC, Vreken P, Andersson HC, et al. Mutations in the 3beta-hydroxysterol Delta24reductase gene cause desmosterolosis, an autosomal recessive disorder of cholesterol biosynthesis. Am J Hum Genet. 2001;69(4):68594.

[87] Hardy J, Allsop D. Amyloid deposition as the central event in the aetiology of Alzheimer's disease. Trends Pharmacol Sci. 1991;12(10):383-88.

[88] Rosario ER, Chang L, Head EH, Stanczyk FZ, Pike CJ. Brain levels of sex steroid hormones in men and women during normal aging and in Alzheimer's disease. Neurobiol Aging. 2011;32(4):604-13.

[89] Yue X, Lu M, Lancaster T, Cao P, Honda S, Staufenbiel M, et al. Brain estrogen deficiency accelerates Abeta plaque formation in an Alzheimer's disease animal model. Proc Natl Acad Sci U S A. 2005;102(52):19198-203.

[90] Medway C, Combarros O, Cortina-Borja M, Butler HT, Ibrahim-Verbaas $\mathrm{CA}$, de Bruijn RF, et al. The sex-specific associations of the aromatase gene with Alzheimer's disease and its interaction with IL10 in the Epistasis Project. Eur J Hum Genet. 2014;22(2):216-20.

[91] Prange-Kiel J, Dudzinski DA, Pröls F, Glatzel M, Matschke J, Rune GM, et al. Aromatase expression in the hippocampus of $A D$ patients and 5xFAD mice. Neural Plast. 2016;9802086.

[92] Brann DW, Dhandapani K, Wakade C, Mahesh VB, Khan MM, et al. Neurotrophic and neuroprotective actions of estrogen: basic mechanisms and clinical implications. Steroids. 2007;72(5):381-405.

[93] Fiocchetti $M$, Ascenzi P, Marino M. Neuroprotective effects of 17betaestradiol rely on estrogen receptor membrane initiated signals. Front Physiol. 2012;3: 73.

[94] Wang JM, Liu L, Brinton RD. Estradiol-17beta-induced human neural progenitor cell proliferation is mediated by an estrogen receptor beta-phosphorylated extracellularly regulated kinase pathway. Endocrinology. 2008;149(1):208-18.

[95] Shao B, Cheng Y, Jin K. Estrogen, neuroprotection and neurogenesis after ischemic stroke. Curr Drug Targets. 2012;13(2):188-98.

[96] Liang Z, Valla J, Sefidvash-Hockley S, Rogers J, Li R. Effects of estrogen treatment on glutamate uptake in cultured human astrocytes derived from cortex of Alzheimer's disease patients. J Neurochem. 2002;80(5):807-14.

[97] Simpkins JW, Yi KD, Yang SH, Dykens JA. Mitochondrial mechanisms of estrogen neuroprotection. Biochim Biophys Acta. 2010;1800(10):1113-20.

[98] Numakawa T, Matsumoto T, Numakawa Y, Richards M, Yamawaki S, Kunugi $\mathrm{H}$. Protective action of neurotrophic factors and estrogen against oxidative stress mediated neurodegeneration. J Toxicol. 2011;405194.

[99] Henderson VW. Alzheimer's disease: review of hormone therapy trials 
and implications for treatment and prevention after menopause. J Steroid Biochem Mol Biol. 2014;142:99-106.

[100] Almeida OP, Flicker L. Association between hormone replacement therapy and dementia: is it time to forget? Int Psychogeriatr. 2005;17(2):155-64.

[101] Henderson VW, Paganini-Hill A, Emanuel CK, Dunn ME, Buckwalter JG. Estrogen replacement therapy in older women. Comparisons between Alzheimer's disease cases and nondemented control subjects. Arch Neurol. 1994:51(9):896-900.

[102] Mulnard RA, Cotman CW, Kawas C, van Dyck CH, Sano M, Doody R, et al. Estrogen replacement therapy for treatment of mild to moderate Alzheimer disease: a randomized controlled trial. Alzheimer's Disease Cooperative Study. JAMA. 2000;283(8):1007-15.

[103] Coker LH, Espeland MA, Rapp SR, Legault C, Resnick SM, Hogan P, et al. Postmenopausal hormone therapy and cognitive outcomes: the Women's Health Initiative Memory Study (WHIMS). J Steroid Biochem Mol Biol. 2010; 118(4-5):304-10.

[104] Li R, He P, Cui J, Staufenbiel M, Harada N, Shen Y. Brain endogenous estrogen levels determine responses to estrogen replacement therapy via regulation of BACE1 and NEP in female Alzheimer's transgenic mice. Mol Neurobiol. 2013;47(3):857-67.

[105] Compton J, van Amelsvoort T, Murphy D. HRT and its effect on normal ageing of the brain and dementia. British J Clin Pharm. 2001;52(6):647-53.

[106] Seshadri S, Zornberg GL, Derby LE, Myers MW, Jick H, Drachman DA. Postmenopausal estrogen replacement therapy and the risk of Alzheimer disease. Arch Neurol. 2001;58(3):435-440.

[107] Butler, H.T., Warden DR, Hogervorst E, Ragoussis J, Smith AD, Lehmann DJ. Association of the aromatase gene with Alzheimer's disease in women. Neurosci Lett. 2010;468(3):202-06.

[108] Arevalo MA, Azcoitia I, Garcia-Segura LM. The neuroprotective actions of oestradiol and oestrogen receptors. Nat Rev Neurosci. 2015;16(1):17-29.

[109] Prange-Kiel J, Wehrenberg U, Jarry H, Rune GM. Para/autocrine regulation of estrogen receptors in hippocampal neurons. Hippocampus. 2003;13(2):226-34.

[110] Li R, Singh M. Sex differences in cognitive impairment and Alzheimer's disease. Front Neuroendocrinol. 2014;35(3):385-403.

[111] Gillies GE, McArthur S. Estrogen actions in the brain and the basis for differential action in men and women: a case for sex-specific medicines. Pharmacol Rev. 2010;62(2):155-98.

[112] Brinton R.D. The healthy cell bias of estrogen action: mitochondrial bioenergetics and neurological implications. Trends Neurosci. 2008;31:529-37.

[113] Li R, Cui J, Shen Y. Brain sex matters: estrogen in cognition and Alzheimer's disease. Mol Cell Endocrinol. 2014;389(1-2):13-21.

[114] Sturchler-Pierrat C, Abramowski D, Duke M, Wiederhold KH, Mistl C, Rothacher $\mathrm{S}$, et al. Two amyloid precursor protein transgenic mouse models with Alzheimer disease-like pathology. Proc Natl Acad Sci U S A. 1997; 94(24):13287-92.

[115] Sturchler-Pierrat C, Staufenbiel M. Pathogenic mechanisms of
Alzheimer's disease analyzed in the APP23 transgenic mouse model. Ann N Y Acad Sci. 2000;920(1):134-9.

[116] McAllister C, Long J, Bowers A, Walker A, Cao P, Honda S, et al. Genetic targeting aromatase in male amyloid precursor protein transgenic mice down-regulates $\beta$-secretase (BACE1) and prevents Alzheimer-like pathology and cognitive impairment. J Neurosci. 2010;30(21):7326-34.

[117] García-Segura LM, Wozniak A, Azcoitia I, Rodriguez JR, Hutchison $\mathrm{RE}$, Hutchison JB. Aromatase expression by astrocytes after brain injury: implications for local estrogen formation in brain repair. Neuroscience. 1999; 89(2):567-78.

[118] Kelicen P, Nordberg A. Feedback Regulation of SREBP and Aromatase in $A \beta$ (25-35)-Supplemented Human Neuroblastoma Cells. Cell Mol Neurobiol. 2006;26(3):225-35.

[119] Veiga S, Azcoitia I, Garcia-Segura LM. Extragonadal synthesis of estradiol is protective against kainic acid excitotoxic damage to the hippocampus. Neuroreport. 2005;16(14):1599-603.

[120] Drew LJ, Fusi S, Hen R. Adult neurogenesis in the mammalian hippocampus: why the dentate gyrus? Learn Mem. 2013;20(12):71029.

[121] Abe K, Tanzi RE, Kogure K. Selective induction of Kunitz-type protease inhibitor domain-containing amyloid precursor protein mRNA after persistent focal ischemia in rat cerebral cortex. Neurosci Lett. 1991:125(2):172-4.

[122] Badan I, Dinca I, Buchhold B, Suofu Y, Walker L, Gratz M, et al. Accelerated accumulation of $\mathrm{N}$ - and C-terminal beta APP fragments and delayed recovery of microtubule-associated protein $1 \mathrm{~B}$ expression following stroke in aged rats. Eur J Neurosci. 2004;19(8):2270-80.

[123] Koistinaho J, Pyykönen I, Keinänen R, Hökfelt T. Expression of beta-amyloid precursor protein mRNAs following transient focal ischaemia. Neuroreport. 1996;7(15-17):2727-2731.

[124] Lin B, Schmidt-Kastner R, Busto R, Ginsberg MD. Progressive parenchymal deposition of $\beta$-amyloid precursor protein in rat brain following global cerebral ischemia. Acta Neuropathol. 1999;97(4):359-68.

[125] Pluta R, Kida E, Lossinsky AS, Golabek AA, Mossakowski MJ, Wisniewski HM. Complete cerebral ischemia with short-term survival in rats induced by cardiac arrest. I. Extracellular accumulation of Alzheimer's $\beta$-amyloid protein precursor in the brain. Brain Res. 1994;649(1-2):323-8.

[126] Shi J, Yang SH, Stubley L, Day AL, Simpkins JW. Hypoperfusion induces overexpression of $\beta$-amyloid precursor protein mRNA in a focal ischemic rodent model. Brain Res. 2000;853(1):1-4.

[127] Koistinaho M, Koistinaho J. Interactions between Alzheimer's disease and cerebral ischemia--focus on inflammation. Brain Res Brain Res Rev. 2005; 48(2):240-50.

[128] Ga D, Fisher M, Macleod M, Davis SM. Stroke. Lancet. 2008;371(9624):612-23.

[129] Giffard RG, Swanson RA. Ischemia-induced programmed cell death in astrocytes. Glia. 2005;50(4):299-306. 
[130] Petrone AB, Rudy CC, Barr TL, Simpkins JW, Reed MN. Chapter 7 Neuroprotective Effects of Estrogen Following Neural Injury. Estrogen Effects on Traumatic Brain Injury: Mechanisms of Neuroprotection and Repair. Elsevier. 2015;91-111.

[131] Gibson CL, Gray LJ, Murphy SP, Bath PM. Estrogens and experimental ischemic stroke: a systematic review. J Cereb Blood Flow Metab. 2006; 26(9):1103-13.

[132] Lekstrom-Himes J, Xanthopoulos KG. Biological role of the CCAAT/ enhancer-binding protein family of transcription factors. J Biol Chem. 1998;273(44): 28545-8.

[133] Soga Y, Yamanaka R, Nishino K, Tanaka R. CCAAT/enhancer binding proteins are expressed in the gerbil hippocampus after transient forebrain ischemia. Neurosci Lett. 2003;337(2):106-10.

[134] Cortés-Canteli M, Wagner M, Ansorge W, Pérez-Castillo A. Microarray analysis supports a role for CCAAT/enhancer-binding protein- $\beta$ in brain injury. J Biol Chem. 2004;279(14):14409-17.

[135] Kelicen-Ugur P, Lule S, Cincioglu M, Pekiner C, Gursoy-Ozdemir Y. Megestrol acetate inhibits the expression of cytoplasmic aromatase through nuclear C/EBP $\beta$ in reperfusion injury-induced ischemic rat hippocampus. Eur J Pharm. 2011;654(3):217-25.

[136] Adibhatla RM, Hatcher J, Dempsey R. Lipids and lipidomics in brain injury and diseases. AAPS J. 2006;8(2):E314-E321.

[137] Adibhatla RM, Dempsey R, Hatcher JF. Integration of cytokine biology and lipid metabolism in stroke. Fron Biosci. 2008;13:1250.

[138] Briggs MR, Yokoyama C, Wang X, Brown MS, Goldstein JL. Nuclear protein that binds sterol regulatory element of low density lipoprotein receptor promoter. I. Identification of the protein and delineation of its target nucleotide sequence. J Biol Chem. 1993;268(19):14490-96.

[139] Taghibiglou C, Martin HG, Lai TW, Cho T, Prasad S, Kojic L, et al. Role of NMDA receptor-dependent activation of SREBP1 in excitotoxic and ischemic neuronal injuries. Nature Med. 2009;15(12):1399.

[140] Azcoitia I, Sierra A, Veiga S, Garcia-Segura LM. Aromatase expression by reactive astroglia is neuroprotective. Ann NY Acad Sci. 2003;1007(1):298-305.

[141] Cincioglu M, Kismali G, Ugur SA, Kelicen-Ugur P. Indinavir inhibits the expression of cytoplasmic aromatase and nuclear SREBP in the hippocampus of reperfusion injury-induced ischemic rats. J Steroid Biochem Mol Biol. 2012; 130(1-2):81-9.

[142] Bengoechea-Alonso MT, Ericsson J. Quelling cholesterol pathway fends off brain damage. Nature Med. 2009;15(12):1358.

[143] Roof RL, Hall ED. Gender differences in acute CNS trauma and stroke: neuroprotective effects of estrogen and progesterone. J Neurotrauma. 2000; 17(5):367-88.

[144] Girijala RL, Sohrabji F, Bush RL. Sex differences in stroke: review of current knowledge and evidence. Vasc Med. 2017;22(2):135-45.

[145] Sohrabji F. Chapter 9 - Cerebrovascular Stroke: Sex Differences and the Impact of Estrogens. Estrogen Effects on Traumatic Brain Injury Mechanisms of Neuroprotection and Repair. Elsevier. 2015;125-141.

[146] Alkayed NJ, Harukuni I, Kimes AS, London ED, Traystman RJ, Hurn PD. Gender-linked brain injury in experimental stroke. Stroke. 1998;29(1):159-166.
[147] Liao S, Chen W, Kuo J, Chen C. Association of serum estrogen level and ischemic neuroprotection in female rats. Neurosci Lett. 2001;297(3):159-62.

[148] Slewa-Younan S, Green AM, Baguley IJ, Gurka JA, Marosszeky JE. Sex differences in injury severity and outcome measures after traumatic brain injury. Arch Physical Med Rehab. 2004;85(3):376-9.

[149] Davis DP, Douglas DJ, Smith W, Sise MJ, Vilke GM, Holbrook TL, et al. Traumatic brain injury outcomes in pre-and post-menopausal females versus age-matched males. J Neurotrauma. 2006;23(2):1408.

[150] van Groen T, Puurunen K, Mäki HM, Sivenius J, Jolkkonen J. Transformation of diffuse beta-amyloid precursor protein and betaamyloid deposits to plaques in the thalamus after transient occlusion of the middle cerebral artery in rats. Stroke. 2005;36(7):1551-6.

[151] Hiltunen $M$, Mäkinen $P$, Peräniemi $S$, Sivenius J, van Groen T, Soininen $\mathrm{H}$, Jolkkonen J. Focal cerebral ischemia in rats alters APP processing and expression of $A \beta$ peptide degrading enzymes in the thalamus. Neurobiol Dis. 2009:35(1):103-13.

[152] Flaim SF, Ratz PH, Swigart SC, Gleason MM. Bepridil hydrochloride alters potential-dependent and receptor-operated calcium channels in vascular smooth muscle of rabbit aorta. J Pharm Exp Ther. 1985;234(1):63-71.

[153] Van FA, Zaagsma J. pH-dependent effects of bepridil on Ca2+extrusion across rat heart sarcolemma. Arch Int Pharm Ther. 1989;298:90-5.

[154] Yatani A, Brown A, Schwartz A. Bepridil block of cardiac calcium and sodium channels. J Pharm Exp Ther. 1986;237(1):9-17.

[155] Mitterreiter S, Page RM, Kamp F, Hopson J, Winkler E, Ha HR, et al. Bepridil and amiodarone simultaneously target the Alzheimer's disease $\beta$-and $\gamma$-secretase via distinct mechanisms. J Neurosci. 2010;30(26):8974-83.

[156] Sarajärvi T, Lipsanen A, Mäkinen $P$, Peräniemi $S$, Soininen $H$, Haapasalo $A$, et al. Bepridil decreases $A \beta$ and calcium levels in the thalamus after middle cerebral artery occlusion in rats. J Cell Mol Med. 2012;16(11): 2754-67.

[157] Fisher RS, Acevedo C, Arzimanoglou A, Bogacz A, Cross JH, Elger $C E$, et al. ILAE official report: a practical clinical definition of epilepsy. Epilepsia. 2014; 55(4):475-82.

[158] Isojärvi J. Disorders of reproduction in patients with epilepsy: antiepileptic drug related mechanisms. Seizure. 2008;17(2):111-9.

[159] Isojarvi J, Laatikainen TJ, Pakarinen AJ, Juntunen KT, Myllylä VV. Polycystic ovaries and hyperandrogenism in women taking valproate for epilepsy. New Eng J Med. 1993;329(19):1383-8.

[160] Krogenaes A, Taubøll E, Stien A, Oskam IC, Lyche JL, Dahl E, et al. Valproate affects reproductive endocrine function, testis diameter and some semen variables in non-epileptic adolescent goat bucks. Theriogenology. 2008;70(1): 15-26.

[161] Logothetis J, Harner R. Electrocortical activation by estrogens. Arch Neurol. 1960;3(3):290-7.

[162] Marcus EM, Watson CW, Goldman PL. Effects of steroids on cerebral electrical activity: epileptogenic effects of conjugated estrogens and 
related compounds in the cat and rabbit. Arch Neurol. 1966;15(5):52132.

[163] Mathern G. Hippocampal sclerosis. Epilepsy: a comprehensive textbook. Editors: Engel J, Pedley TA, Aicardi J. Lippincott Williams \& Wilkins, Vol.3 1997:133-155.

[164] Mikkonen K, Tapanainen P, Pakarinen AJ, Päivänsalo $M$, Isojärvi Jl, Vainionpää LK. Serum androgen levels and testicular structure during pubertal maturation in male subjects with epilepsy. Epilepsia. 2004;45(7):769-76.

[165] Svalheim S, Sveberg L, Mochol M, Taubøll. Interactions between antiepileptic drugs and hormones. Seizure. 2015;28:12-17.

[166] Sveberg Røste L, Taubøll E, Berner A, Berg KA, Aleksandersen M, Gjerstad L. Morphological changes in the testis after long-term valproate treatment in male Wistar rats. Seizure. 2001;10(8):559-65.

[167] Sveberg Røste L, Taubøll E, Isojärvi JI, Pakarinen AJ, Huhtaniemi IT, Knip M, et al. Effects of chronic valproate treatment on reproductive endocrine hormones in female and male Wistar rats. Reprod Toxicol. 2002;16(6):767-73.

[168] Baird, AD, Wilson SJ, Bladin PF, Saling MM, Reutens DC. The amygdala and sexual drive: insights from temporal lobe epilepsy surgery. Ann Neurol. 2004; 55(1):87-96.

[169] Daniele, A., Azzoni A, Bizzi A, Rossi A, Gainotti G, Mazza S. Sexual behavior and hemispheric laterality of the focus in patients with temporal lobe epilepsy. Biol Psychiatry. 1997;42(7):617-24.

[170] Quigg M, Kiely JM, Shneker B, Veldhuis JD, Bertram EH 3rd. Interictal and postictal alterations of pulsatile secretions of luteinizing hormone in temporal lobe epilepsy in men. Ann Neurol. 2002:51(5):559-66.

[171] Chan KW, Kalra S, Kirby RM, Brunt AM, Hawkins CP. Epileptic seizure abolition with aromatase inhibition. J Neurol Neurosurg Psychiatry. 2012; 83(12):1249-50.

[172] Herzog AG. Psychoneuroendocrine aspects of temporolimbic epilepsy: Part II: Epilepsy and reproductive steroids. Psychosomatics. 1999;40(2):102-8.

[173] Velíšková J. Estrogens and epilepsy: why are we so excited? Neuroscientist. 2007;13(1):77-88.

[174] Herzog AG. Catamenial epilepsy: definition, prevalence pathophysiology and treatment. Seizure. 2008;17(2):151-9.

[175] Velíšková J. The role of estrogens in seizures and epilepsy: the bad guys or the good guys? Neuroscience. 2006;138(3):837-44.

[176] Velišková J, DeSantis KA. Sex and hormonal influences on seizures and epilepsy. Horm Behav. 2013;63(2):267-77.

[177] Muftuoglu Y, Mustata G. Aromatase inhibitors and antiepileptic drugs: a computational systems biology analysis. Rep Biol Endoc. 2011;9(1):92.

[178] Harden C, MacLusky NJ. Aromatase inhibition, testosterone, and seizures. Epilepsy Behav. 2004;5(2):260-3.

[179] Herzog AG, Fowler KM. Sexual hormones and epilepsy: threat and opportunities. Curr Op Neurol. 2005;18(2):167-72.

[180] Harden C, MacLusky NJ. Aromatase inhibitors as add-on treatment for men with epilepsy. Expert Rev Neurother. 2005;5(1):123-7.

[181] Santen R, Brodie H, Simpson ER, Siiteri PK, Brodie A. History of aromatase: saga of an important biological mediator and therapeutic target. Endocrine Rev. 2009;30(4):343-75.

[182] de Ronde W. Therapeutic uses of aromatase inhibitors in men. Curr Opin Endocrinol Diabetes and Obes. 2007;14(3):235-40.

[183] Sutula T, Cascino G, Cavazos J, Parada I, Ramirez L. Mossy fiber synaptic reorganization in the epileptic human temporal lobe. Ann Neurol. 1989;26(3): 321-30.

[184] Fabian C. The what, why and how of aromatase inhibitors: hormonal agents for treatment and prevention of breast cancer. Int J Clin Prac. 2007;61(12): 2051-63.

[185] Cincioglu-Palabiyik M, Üner M, Ertoy-Baydar D, Sara Y, Karahan $\mathrm{H}$, Kelicen-Uğur P. Chronic levetiracetam decreases hippocampal and testicular aromatase expression in normal but not kainic acidinduced experimental model of acute seizures in rats. Neuroreport. 2017;28(14):903-9.

[186] Kühn-Velten WN, Herzog AG, Müller MR. Acute effects of anticonvulsant drugs on gonadotropin-stimulated and precursorsupported androgen production in the rat testis. Eur J Pharm. 1990;181(1-2):151-5.

[187] Isojärvi, Jl, Taubøll E, Herzog AG. Effect of antiepileptic drugs on reproductive endocrine function in individuals with epilepsy. CNS Drugs. 2005;19(3):207-23.

[188] Herzog AG, Drislane FW, Schomer DL, Pennell PB, Bromfield EB, Dworetzky $B A$, et al. Differential effects of antiepileptic drugs on sexual function and hormones in men with epilepsy. Neurology. 2005;65(7):1016-20.

[189] Heroz, AG, Levesque LA, Drislane FW, Ronthal M, Schomer DL. Phenytoin-induced elevation of serum estradiol and reproductive dysfunction in men with epilepsy. Epilepsia. 1991;32(4):550-3.

[190] Herzog A. Reproductive endocrine regulation in men with epilepsy: effects on reproductive function and neuronal excitability. Ann Neurol. 2002;51:539-42.

[191] Mintzer S. Metabolic consequences of antiepileptic drugs. Curr Opin Neurol. 2010;23(2):164-9.

[192] von Krogh K, Harjen H, Almås C, Zimmer KE, Dahl E, Olsaker I, et al. The effect of valproate and levetiracetam on steroidogenesis in forskolin-stimulated H295R cells. Epilepsia. 2010;51(11):2280-8.

[193] Morrell M. Epilepsy in women. American Family Physician. 2002;66(8):1489-94.

[194] Aguilar JA, Martin HL, McNaughton FL. Aminoglutethimide in the treatment of epilepsy. Can Med Assoc J. 1961;84:374-6.

[195] Cohen MH, Johnson JR, Li N, Chen G, Pazdur R. Approval summary: letrozole in the treatment of postmenopausal women with advanced breast cancer. Clin Cancer Res. 2002;8(3):665-9.

[196] Rashid D, Panda BP, Vohora D. Reduced estradiol synthesis by letrozole, an aromatase inhibitor, is protective against development of pentylenetetrazole-induced kindling in mice. Neurochem Int. 2015;90:271-4.

[197] Reddy DS. Testosterone modulation of seizure susceptibility is mediated by neurosteroids 3alpha-androstanediol and 17betaestradiol. Neuroscience. 2004; 129(1):195-207. 
[198] Zhou L, Fester L, von Blittersdorff B, Hassu B, Nogens H, Prange-Kiel J, Jarry H, Wegscheider K, Rune GM. Aromatase inhibitors induce spine synapse loss in the hippocampus of ovariectomized mice. Endocrinology. 2010; 151(3):1153-60.

[198] Leranth C, Hajszan T, MacLusky NJ. Androgens increase spine synapse density in the CA1 hippocampal subfield of ovariectomized female rats. J Neurosci. 2004;24:495-99.

[200] Vierk R, Glassmeier G, Zhou L, Brandt N, Fester L, Dudzinski D, Wilkars W, Bender RA, Lewerenz M, Gloger S, Graser L, Schwarz J, Rune GM. Aromatase inhibition abolishes LTP generation in female but not in male mice. J Neurosci. 2012;32(24):8116-26. 